\title{
Penerapan pendekatan cinematherapy untuk meningkatkan perilaku prososial pada siswa Bosowa International School Makassar
}

\author{
Haeruddin Niva \\ Bimbingan dan Konseling, Bosowa Internasional School Makassar \\ Email: niva_haeruddin@yahoo.com
}

(Diterima: 12-Maret-2016; direvisi: 1-Juni-2016; dipublikasikan: 28-Juni-2016)

\begin{abstract}
The objectives of the research are: (1) to know the prosocial behavioral level of the students in Bosowa International School Makassar before and after giving cinematography approach, and (2) to know whether or not the approach is able to enhance the prosocial behavior of the students in Bosowa International School Makassar. The research is a quantitative research using experimental method. The research design used is quasi experimental design with non-equivalent control group design. The data collection technique applied is scale and FGD (Focus Group Discussion). The findings shows that (1) the prosocial behavioral level of the students was low in pretest while after giving treatment there were significant increase to the prosocial behavior in the experimental group, and (2) the cinematography approach was able to increase the prosocial behavior of the Grade VIII students in Bosowa Internatinal School Makassar.
\end{abstract}

Keywords: Cinemateraphy, prosocial behavior.

\begin{abstract}
Abstrak: Tujuan penelitian ini adalah (1) untuk mengetahui tingkat perilaku prososial siswa di Bosowa International School Makassar sebelum dan sesudah diberikan cinematherapy, dan (2) untuk mengetahui pendekatan cinematherapy mampu meningkatkan perilaku prososial siswa di Bosowa International School Makassar. Penelitian ini merupakan penelitian kuantitatif dengan menggunakan pendekatan eksperimen. Adapun desain eksperimen yang digunakan di dalam penelitian ini adalah quasi experimental design dalam bentuk nonequivalent control group design. Penelitian ini menggunakan teknik pengumpulan data melalui skala dan FGD (Focuss Group Discussion). Hasil penelitian menunjukkan bahwa (1) tingkat perilaku prososial siswa rendah saat pretest sedangkan setelah pemberian perlakuan maka terjadi peningkatan yang signifikan terhadap perilaku prososial pada kelompok eksperimen, dan (2) pendekatan cinematherapy mampu meningkatkan perilaku prososial pada siswa kelas VIII di Bosowa International School Makassar.
\end{abstract}

Kata Kunci: Cinematherapy, perilaku prososial.

Copyright (C) 2016 Universitas Negeri Makassar. This is an open access article under the CC BYNC-ND license (http://creativecommons.org/licenses/by-nc-nd/4.0/).

\section{PENDAHULUAN}

Dalam kehidupan sehari-hari manusia tidak bisa lepas dari tolong-menolong serta mempunyai kepedulian terhadap orang lain. Faturrohman (2009: 14), mengemukakan bahwa "Setinggi apapun kemandirian seseorang pada saat tertentu dia akan membutuhkan orang lain". Perilaku menolong menggambarkan manusia sebagai makhluk yang tidak egois dan dermawan, mampu untuk memberikan perhatian yang nyata untuk kesejahteraan orang lain, dan merasa bahwa dirinya mempunyai kemampuan memberikan bantuan pada orang lain. 
Perilaku menolong manusia yang dilakukan tanpa pamrih dan tidak mengandung maksud tertentu secara umum dikenal dengan perilaku prososial. Taylor et al. (2009: 457) mendefinisikan perilaku prososial sebagai setiap tindakan manusia yang membantu orang dan memiliki konsekuensi positif pada orang lain. Untuk melihat tingkat perilaku prososial pada individu dapat dilihat pada aspek berbagi/sharing, kerja sama/cooperating, menolong/helping, bertindak jujur/honesty, dan berderma/donating (Mussen, Conger, \& Kagan dalam Asih: 2012).

Perilaku prososial berkembang dimulai sejak masa anak-anak hingga masa dewasa. Semakin bertambah usia seseorang, semakin berkembang kematangan sosial dan tanggung jawab sosialnya. Pada usia remaja, seseorang sudah harus mampu mengembangkan pribadinya, sehingga sesuai dengan nilai etika dan moral dalam bentuk perilaku sosial. Prososial pada seseorang yang didasarkan pada nilai etika, moral dan adat-istiadat semestinya menciptakan keharmonisan pada masyarakat tersebut. Namun pada kenyataannya, nilai-nilai prososial yang ada di masyarakat semakin menunjukkan kemunduran. Hal ini terutama banyak dialami oleh para remaja.

Hamidah (Isnandar, 2010: 4) menemukan bahwa di tujuh daerah di Jawa Timur menunjukkan adanya indikasi penurunan kepedulian sosial dan kepekaan pada remaja terhadap orang lain dan lingkungannya. Remaja tampak lebih mementingkan diri sendiri dalam meraih keberhasilan, tanpa banyak mempertimbangkan keadaan orang lain di sekitarnya. Hal itu dapat menyebabkan remaja menjadi semakin individualis sehingga perilaku sosial yang dimiliki semakin pudar.

Perilaku prososial sangat dibutuhkan oleh orang-orang yang membutuhkan bantuan seperti siswa yang mengalami masalah. Oleh karena itu perilaku prososial harus dimiliki oleh setiap siswa. Berkaitan dengan hal itu, dilakukan observasi pada seluruh siswa kelas VIII yang berjumlah 50 siswa di Bosowa International School Makassar pada awal Juni 2015. Hasil observasi menunjukkan bahwa terdapat beberapa siswa yang menunjukkan gejala perilaku prososial yang rendah. Indikasi yang nampak adalah siswa kurang peduli terhadap diri sendiri dan orang lain. Siswa tidak peduli terhadap kondisi kelas yang kotor, susunan kursi yang tidak tertata rapi, masih rendahnya kerja sama yang dilakukan oleh siswa, siswa sibuk dengan urusannya masing-masing bahkan siswa tidak memedulikan teman sekelasnya ketika ada siswa yang tidak masuk sekolah selama tiga hari berturut-turut.

Bosowa International School Makassar menerapkan sistem boarding. Dengan kata lain, seluruh siswa diwajibkan untuk tinggal di dalam asrama. Siswa hanya diberi waktu untuk bertemu dengan orang tua pada akhir pekan. Berkaitan dengan itu, maka perlu kiranya dilakukan observasi pula pada asrama yang menjadi tempat tinggal siswa. Berdasarkan observasi yang dilakukan ditemukan bahwa siswa menampakkan ketidakpedulian terhadap kondisi kebersihan di lingkungan asrama, terbentuk kelompokkelompok berdasarkan pertimbangan daerah asal, serta ketidakpedulian terhadap teman yang tinggal bersama. Indikasi yang nampak adalah siswa malas membuang sampah ketika sampah sudah penuh pada tempat sampah, enggan membersihkan kamar tidur serta kamar mandi, lebih memilih menunggu teman yang membersihkan daripada berinisiatif sendiri untuk membersihkan, siswa yang berasal dari daerah $\mathrm{A}$ misalnya enggan untuk bergaul dan membuka diri terhadap siswa yang berasal dari daerah B, rendahnya kerja sama yang dilakukan oleh siswa, bahkan siswa tidak memedulikan teman sekelasnya ketika ada siswa yang sakit atau membutuhkan bantuan.

Hasil observasi yang dilakukan kemudian ditindaklanjuti dengan melakukan penyebaran skala perilaku prososial yang dibuat secara sederhana oleh peneliti pada minggu kedua Juni 2015. Rumusan pada skala mengacu pada indikator perilaku prososial yang dikemukakan oleh Mussen, Conger, \& Kagan dalam Asih (2012) yakni berbagi/sharing, kerja sama/ cooperating, menolong/helping, bertindak jujur/honesty, dan berderma/donating. Skala disebar kepada seluruh siswa kelas VIII yang berjumlah 50 orang. Dari keseluruhan siswa kelas VIII yang berjumlah 50 orang, 34 siswa atau $68 \%$ siswa memiliki perilaku prososial yang rendah yang dapat dilihat dari aspek berbagi, menolong, kerja sama, bertindak jujur, dan berderma. Hasil ini menunjukkan bahwa perlu ada upaya serius dari unit Bimbingan dan Konseling (selanjutnya di dalam penulisan ini disingkat BK) dalam menangani permasalahan ini. 
Penanganan masalah rendahnya perilaku prososial siswa di Bosowa International School Makassar dilakukan dengan memberikan layanan informasi, konseling perorangan, bimbingan kelompok maupun konseling kelompok. Layanan informasi yang diberikan berkaitan dengan materi-materi yang berhubungan dengan aspekaspek sosial siswa, misalnya etika pergaulan, tata cara bergaul dengan lawan jenis, cara berkomunikasi santun dengan teman, dan sebagainya. Untuk konseling, baik secara individual maupun kelompok disesuaikan dengan masalah yang dihadapi oleh siswa. Sementara itu, layanan bimbingan kelompok diberikan untuk membantu siswa dalam mencegah perilaku-perilaku negatif yang berpotensi muncul di kalangan siswa sehubungan dengan perilaku prososial yang rendah, misalnya bullying.

Upaya-upaya yang telah dilakukan belum menunjukkan hasil yang optimal. Untuk itu, dilakukan evaluasi mendalam untuk mencari jalan keluar permasalahan perilaku prososial yang rendah pada siswa. Berdasarkan kajian literatur dan pertimbangan-pertimbangan karakteristik usia siswa, diupayakan suatu teknik untuk meningkatkan perilaku prososial siswa di Bosowa International School Makassar. Upaya itu adalah melalui penerapan cinematherapy.

Menurut Berg-Cross, Jennings \& Brunch dalam Joseph (2015) cinematherapy adalah teknik terapeutik khusus yang di dalamnya menggunakan film komersial yang dipilih untuk mendapatkan arti terapeutik pada klien tentang pandangan terhadap individu atau terhadap orang lain. Film menyajikan potensi kekuatan baru untuk menerangi kedalaman pengalaman manusia. Cinematherapy membuat kekuatan itu sebagai alat untuk meningkatkan kesadaran. Melalui cinematherapy, konseli akan belajar dalam mencari dan menemukan suatu wawasan baru dalam memandang fenomena sosial yang terjadi di lingkungan sekitarnya.

Alasan penggunaan cinematherapy yakni siswa senang menonton film. Film termasuk ke dalam kategori audiovisual yang menyajikan tampilan gambar gerak dan suara, gambar gerak digunakan untuk merangsang siswa melalui indra penglihatan dan suara digunakan untuk merangsang siswa melalui indra pendengaran. Penggabungan indra penglihatan dan pendengaran diharapkan menjadikan siswa lebih mudah menyerap informasi yang diberikan.
Para ahli juga memilki pandangan yang sama akan hal itu, perolehan hasil belajar melalui indra penglihatan dan indra pendengar sangat menonjol perbedaannya. Menurut Baugh (Nurjanah, 2013: 5), kurang lebih 90\% hasil belajar seseorang diperoleh melalui indra pandang, hanya 5\% diperoleh melalui indra dengar dan 5\% lagi dengan indra lainnya. Di lain pihak, Yazici et al. (2014: 256) mengemukakan bahwa film dibuat dengan tujuan utama untuk menghibur, tetapi kini film dibuat untuk meningkatkan kesehatan perilaku individu.

Bertolak dari uraian yang dijelaskan sebelumnya, maka peneliti tertarik untuk melakukan penelitian yang berjudul "Penerapan Pendekatan Cinematherapy Untuk Meningkatkan Perilaku Prososial Siswa di Bosowa International School Makassar".

Berdasarkan uraian sebelumnya, maka tujuan penelitian ini adalah untuk mengetahui: (1) gambaran pelaksanaan cinematherapy kepada siswa di Bosowa International School Makassar, (2) Tingkat perilaku prososial siswa di Bosowa International School Makassar sebelum dan sesudah diberikan cinematherapy dan (3) Apakah cinematherapy mampu meningkatkan perilaku prososial siswa di Bosowa International School Makassar.

\section{METODE}

Penelitian ini merupakan penelitian kuantitatif dengan menggunakan pendekatan eksperimen. Desain eksperimen yang digunakan di dalam penelitian ini adalah quasi experimental design dalam bentuk nonequivalent control group design. Populasi pada penelitian ini adalah seluruh siswa kelas VIII Bosowa International School Makassar yang terdaftar dan aktif mengikuti pembelajaran pada semester ganjil tahun ajaran 2015/2016 yang berjumlah 50 siswa. Penarikan sampel dalam penelitian ini menggunakan nonprobability sampling dengan teknik purposive sampling. Sampel dari penelitian ini berjumlah 34 siswa yang terbagi ke dalam dua kelompok, yakni 17 siswa kelompok eksperimen dan 17 siswa kelompok kontrol. Data dikumpulkan melalui skala, observasi, dan Focuss Group Discussion (FGD).

\section{HASIL DAN PEMBAHASAN}


Gambaran pelaksanaan cinematherapy. Pelaksanaan cinematherapy dilakukan sebanyak delapan kali pertemuan dengan rincian satu kali pretest, satu kali pertemuan untuk menentukan sampel pada kelompok eksperimen dan kontrol, empat kali pertemuan dalam rangka pelaksanaan cinematherapy kepada sampel penelitian, satu kali pertemuan untuk Focuss Group Discussion, dan satu kali pertemuan untuk pelaksanaan posttest.

Pertemuan pertama dilakukan untuk melakukan pretest dengan tujuan untuk mengetahui tingkat perilaku prososial siswa sebelum diberikan perlakuan. Pada pertemuan kedua dilakukan pembagian sampel ke dalam kelompok eksperimen dan kelompok kontrol. Berdasarkan jumlah sampel sebanyak 34 siswa, maka ditetapkan 17 siswa masuk ke dalam kelompok eksperimen dan 17 siswa ke dalam kelompok kontrol.

Pada pertemuan ketiga, keempat, kelima, dan keenam cinematherapy dilakukan. Film yang diputarkan adalah Bidadari-Bidadari Surga,
Kung Fu Panda 2, Lima Elang, dan Sang Pemimpi. Saat pemutaran film peneliti melakukan observasi terhadap kegiatan yang dilakukan oleh sampel selama pemberian perlakuan. Pada setiap akhir kegiatan menonton, siswa diperintahkan untuk berdiskusi berdasarkan hasil tontonannya.

Pada pertemuan ketujuh dilakukan FGD. Hasil dari FGD menyimpulkan bahwa pada prinsipnya siswa memandang cinematherapy bermanfaat dalam menangani permasalahan yang terjadi dalam kehidupan sehari-hari. Upaya ini dapat menjadi sebuah media baru yang dapat membantu praktisi BK di lapangan dalam membantu siswa untuk menghadapi permasalahan yang ditimbulkan dalam bidang kehidupan sosial siswa.

Gambaran tingkat perilaku prososial siswa sebelum dan setelah penerapan cinematherapy untuk kelompok eksperimen dapat dilihat pada tabel berikut.

Tabel 4.1 Data Tingkat Perilaku prososial Siswa Kelas VIII Bosowa International School Makassar Sebelum (Pretest) dan Setelah (Posttest) Diberi Perlakuan Berupa Cinematherapy pada Kelompok Eksperimen

\begin{tabular}{|c|c|c|c|c|c|}
\hline \multirow[b]{2}{*}{ Interval } & \multirow[b]{2}{*}{ Kategorisasi } & \multicolumn{2}{|c|}{ Pretest Eksperimen } & \multicolumn{2}{|c|}{ Posttest Eksperimen } \\
\hline & & Frekuensi & $\begin{array}{c}\text { Persentase } \\
(\%)\end{array}$ & Frekuensi & $\begin{array}{c}\text { Persentase } \\
(\%)\end{array}$ \\
\hline$\geq 113$ & Sangat Tinggi & 0 & 0 & 2 & 11,76 \\
\hline $98-112$ & Tinggi & 0 & 0 & 9 & 52,94 \\
\hline $83-97$ & Sedang & 3 & 17,65 & 2 & 11,76 \\
\hline $68-82$ & Rendah & 10 & 58,82 & 3 & 17,65 \\
\hline$<67$ & Sangat Rendah & 4 & 23,53 & 1 & 5,88 \\
\hline \multicolumn{2}{|c|}{ Jumlah } & 17 & 100 & 17 & 100 \\
\hline
\end{tabular}

Sumber: Hasil pengolahan data

Berdasarkan tabel 4.1 hasil pretest ditemukan bahwa tingkat perilaku prososial siswa kelas VIII Bosowa International School Makassar pada kelompok eksperimen sebelum diberi cinematherapy adalah terdapat empat siswa $(23,53 \%)$ berada pada kategori sangat rendah, sepuluh siswa $(58,82 \%)$ berada pada kategori rendah, tiga siswa $(17,65 \%)$ berada pada kategori sedang, dan tidak terdapat siswa $(0 \%)$ yang berada pada kategori yang tinggi dan sangat tinggi. Namun setelah diberikan perlakuan berupa cinematherapy, maka terjadi peningkatan tingkat perilaku prososial siswa.
Berdasarkan hasil posttest diketahui bahwa terdapat satu siswa $(5,88 \%)$ yang tingkat perilaku prososialnya pada kategori sangat rendah, tiga siswa $(17,65 \%)$ yang tingkat perilaku prososialnya pada kategori rendah, dua siswa $(11,76 \%)$ tingkat perilaku prososialnya pada kategori sedang dan sangat tinggi, serta sembilan siswa $(52,94 \%)$ yang tingkat perilaku prososialnya pada kategori tinggi. Hasil ini menginformasikan bahwa tingkat perilaku prososial siswa pada kelompok eksperimen saat pretest dapat dikategorikan "rendah" sedangkan setelah diberikan perlakuan maka tingkat 
perilaku prososial siswa dapat dikategorikan "tinggi".

Gambaran tingkat perilaku prososial siswa sebelum dan setelah penerapan cinematherapy

Tabel 4.3 Data Tingkat Perilaku prososial Siswa Kelas VIII Bosowa International School Makassar Sebelum dan Setelah Diberi Layanan Informasi pada Kelompok Kontrol untuk kelompok kontrol dapat dilihat pada tabel berikut.

\begin{tabular}{cccccc}
\hline \multirow{2}{*}{ Interval } & \multirow{2}{*}{ Kategorisasi } & \multicolumn{2}{c}{ Pretest Kontrol } & \multicolumn{2}{c}{ Posttest Kontrol } \\
\cline { 3 - 6 } & & Frekuensi & Persentase & Frekuensi & Persentase \\
\hline$\geq 113$ & Sangat Tinggi & 0 & 0 & 0 & 0 \\
$98-112$ & Tinggi & 2 & 11,76 & 0 & 0 \\
$83-97$ & Sedang & 5 & 29,41 & 7 & 41,18 \\
$68-82$ & Rendah & 7 & 41,18 & 7 & 41,18 \\
$<67$ & Sangat Rendah & 3 & 17,65 & 3 & 17,65 \\
\hline \multicolumn{2}{r}{ Jumlah } & $\mathbf{1 7}$ & $\mathbf{1 0 0}$ & $\mathbf{1 7}$ & $\mathbf{1 0 0}$ \\
\hline
\end{tabular}

Sumber: Hasil Inventori Penelitian Kelompok Kontrol

Berdasarkan tabel 4.3, gambaran tingkat perilaku prososial siswa untuk kelompok kontrol saat pretest adalah tidak terdapat siswa $(0 \%)$ yang tingkat perilaku prososialnya berada pada kategori sangat tinggi, dua siswa $(11,76 \%)$ tingkat perilaku prososialnya berada pada kategori tinggi, lima siswa $(29,41 \%)$ tingkat perilaku prososialnya pada kategori sedang, tujuh siswa $(41,18 \%)$ berada pada kategori rendah, serta tiga siswa $(17,65 \%)$ yang tingkat perilaku prososialnya berada pada kategori sangat rendah.

Setelah diberikan perlakuan berupa layanan informasi tentang perilaku prososial serta alternatif penanganannya maka tingkat perilaku prososial siswa yaitu tidak terdapat siswa $(0 \%)$ yang tingkat perilaku prososialnya berada pada kategori sangat tinggi dan tinggi, tujuh siswa
$(41,18 \%)$ yang tingkat perilaku prososialnya berada pada kategori sedang dan rendah, serta tiga siswa $(17,65 \%)$ tingkat perilaku prososialnya berada pada kategori sangat rendah. Kondisi ini menunjukkan bahwa belum terdapat perubahan yang signifikan terhadap sampel yang tergabung dalam kelompok kontrol. Hasil ini mengindikasikan bahwa tingkat perilaku prososialsiswa pada kelompok kontrol baik itu pada saat pretest maupun posttest dapat dikategorikan "rendah".

Adapun hasil analisis uji wilcoxon pada pretest dan posttest terhadap tingkat perilaku prososial siswa pada kelompok eksperimen di Bosowa International School Makassar dapat dilihat pada tabel 4.10 sebagai berikut.

Tabel 4.10 Hasil Analisis Hipotesis Tingkat Perilaku prososialSiswa Melalui Wilcoxon Signed RanksTest pada Kelompok Eksperimen

\begin{tabular}{cccccc}
\hline Kelompok Data & N & Rata-rata & Gain Skor & Z & Asyimp. Sig \\
\hline $\begin{array}{c}\text { Posttest } \\
\text { Pretest }\end{array}$ & 17 & 97,82 & \multirow{2}{*}{24,7} & $-3,625$ & 0,000 \\
& & 73,12 & &
\end{tabular}

Sumber: Hasil Analisis Hipotesis Melalui Wilcoxon Signed Rangks Test

Berdasarkan hasil analisis uji wilcoxon dengan menggunakan SPSS 20,0 for windows diketahui bahwa terdapat perbedaan signifikan nilai rata-rata setelah perlakuan lebih tinggi dari pada sebelum diberikan perlakuan pada kelompok eksperimen. Selanjutnya, hal ini dipertegas dari nilai gain score pada kelompok eksperimen yaitu 24,7.
Berdasarkan uji statistik diperoleh nilai $Z$ sebesar-3,625 dengan nilai asyimp. sig $=0,000<0,05$, hal ini berarti bahwa hipotesis nihil $\left(\mathrm{H}_{0}\right)$ yang berbunyi "penerapan cinematherapy tidak mampu meningkatkan tingkat perilaku prososial pada siswa VIII Bosowa International School Makassar" dinyatakan ditolak. Sehingga hipotesis kerja $\left(\mathrm{H}_{1}\right)$ yang berbunyi "penerapan cinematherapy 
mampu meningkatkan tingkat perilaku prososial pada siswa VIII Bosowa International School Makassar" dinyatakan diterima. Dasar pengambilan keputusan ini adalah hasil uji beda yaitu nilai asyimp. Sig $=0,000$ lebih kecil daripada taraf kesalahan yang ditetapkan yaitu sebesar 0,05.

Berdasarkan hasil analisis uji wilcoxon dengan menggunakan SPSS 20,0 for windows diketahui bahwa terdapat perbedaan kurang signifikan nilai rata-rata setelah perlakuan yang lebih tinggi dari pada sebelum diberikan perlakuan pada kelompok kontrol. Selanjutnya, hal ini dipertegas dari nilai gain score pada kelompok kontrol yaitu 4,76. Berdasarkan uji statistik diperoleh nilai $Z$ sebesar-1,944dengan nilai asyimp. sig $=0,052>0,05$, hal ini berarti bahwa hipotesis nihil $\left(\mathrm{H}_{0}\right)$ yang berbunyi "penerapan layanan informasi tidak mampu meningkatkan tingkat perilaku prososial pada siswa VIII Bosowa International School Makassar" dinyatakan diterima dan hipotesis kerja $\left(\mathrm{H}_{1}\right)$ dinyatakan ditolak. Dasar pengambilan keputusan ini adalah hasil uji beda yaitu nilai asyimp. Sig $=0,052$ lebih besar dari pada taraf kesalahan yang ditetapkan yaitu sebesar 0,05 .

Berdasarkan hasil uji hipotesis yang dilakukan maka dapat disimpulkan bahwa penerapan cinematherapy efektif dalam meningkatkan perilaku prososial pada siswa kelas VIII Bosowa International School Makassar. Hal ini dibuktikan berdasarkan uji statistik yang dilakukan pada kelompok eksperimen. Sementara itu, penerapan layanan informasi tidak efektif dalam meningkatkan perilaku prososial pada siswa kelas VIII Bosowa International School Makassar. Hal ini diperkuat dengan uji statistik yang dilakukan pada kelompok kontrol. Hal ini mengaskan bahwa cinematherapy lebih efektif dalam menurunkan tingkat perilaku prososial dari pada penerapan layanan informasi pada siswa kelas VIII Bosowa International School Makassar.

Perilaku prososial merupakan perilaku yang terpuji. Perilaku ini mampu menjadikan individu sebagai makhluk yang mampu menggapai aktualisasi diri. Namun pada kenyataannya tidak semua individu mampu untuk memiliki perilaku ini dan tak jarang kehidupan sosial diselimuti dengan konflik yang disebabkan oleh individu tidak mampu untuk berprososial baik itu terhadap individu lain maupun terhadap kelompok dan komunitas lain. Salah satu upaya yang dapat dilakukan untuk mengatasi masalah tersebut adalah melalui cinematherapy.

Cinematherapy adalah salah satu bentuk teknik terapi yang menggunakan film sebagai wahana terapi. Cinematherapy mempunyai sifat penyembuhan metaforis terapeutik yang telah digunakan dengan kelompok populasi yang luas. Namun, penelitian ini mengeksplorasi penggunaan cinematherapy dengan siswa, karena siswa memiliki tantangan perkembangan yang unik karena mereka mengalami transisi dari masa kanak-kanak sampai remaja. Mereka menjadi kurang terlibat dengan lingkungan keluarga dekat dan mencari informasi dan pengalaman dari luar keluarga. Pertumbuhan fisik, perkembangan seksual, pengembangan hubungan romantis, perkembangan kognitif, sosial dan emosional yang akut dipengaruhi oleh lingkungan mereka. Siswa menggunakan media untuk berbagai tujuan, seperti membentuk identitas mereka sendiri, mengatasi masalah, dan berhubungan dengan teman-temannya (Wu dalam Sopian: 2015).

Berdasarkan studi pendahuluan di Bosowa International School Makassar menunjukkan bahwa siswa kelas VIII terindikasi mengalami penurunan tingkat perilaku prososial. Indikasi yang nampak adalah siswa kurang peduli terhadap diri sendiri dan orang lain. Siswa tidak peduli terhadap kondisi kelas yang kotor, susunan kursi yang tidak tertata rapi, masih rendahnya kerja sama yang dilakukan oleh siswa, siswa sibuk dengan urusannya masing-masing bahkan siswa tidak memedulikan teman sekelasnya ketika ada siswa yang tidak masuk sekolah selama tiga hari berturut-turut. Hal ini kemudian diikuti oleh hasil penyebaran skala perilaku prososial yang dibuat secara sederhana oleh peneliti. Skala disebar kepada seluruh siswa kelas VIII yang berjumlah 50 orang. Dari keseluruhan siswa kelas VIII yang berjumlah 50 orang, 34 siswa atau $68 \%$ siswa memiliki perilaku prososial yang rendah yang dapat dilihat dari aspek berbagi, menolong, kerja sama, bertindak jujur, dan berderma.

Melalui pretest terhadap 17 siswa pada kelompok eksperimen dan 17 siswa pada kelompok kontrol ditemukan bahwa siswa memiliki tingkat perilaku prososial yang rendah. Namun demikian, untuk kelompok eksperimen setelah diberi perlakuan berupa cinematherapy berdasarkan prosedur yang telah ditetapkan, 
ternyata mengalami peningkatan perilaku prososial. Siswa yang berada pada perilaku prososial yang rendah meningkat menjadi tinggi. Lain halnya dengan kelompok kontrol yang tidak diberikan perlakuan berupa cinematherapy. Penerapan layanan informasi kurang menunjukkan perubahan yang signifikan dalam meningkatkan perilaku prososial siswa sehingga ditemukan siswa yang perilaku prososialnya berada pada kategori yang rendah.

Hasil penelitian mengungkapkan bahwa terjadi peningkatan yang signifikan terhadap perilaku prososial siswa pada kelompok eksperimen setelah dilakukan cinematherapy. Hal ini diperkuat oleh hasil uji statistik yang menyatakan bahwa cinematherapy terbukti secara signifikan mampu meningkatkan perilaku prososial siswa. Sementara itu, pada kelompok kontrol yang tidak diberikan cinematherapy tidak menunjukkan peningkatan perilaku prososial yang signifikan. Hal ini diperkuat oleh hasil uji statistik yang menyatakan bahwa layanan informasi sebagai bentuk perlakuan yang diberikan kepada kelompok kontrol terbukti secara signifikan tidak mampu meningkatkan perilaku prososial siswa. Berdasarkan uraian tersebut, cinematherapy mampu meningkatkan perilaku prososial pada siswa kelas VIII di Bosowa International School Makassar.

Terjadinya peningkatan yang siginifikan terhadap perilaku prososial siswa melalui pemberian cinematherapy disebabkan oleh efek sinema atau film yang diberikan. Melalui hasil penelitiannya, Smithikrai, Longthong, \& Peijsel (2015) ditemukan bahwa film mampu meningkatkan kompetensi sosial individu. Lebih lanjut Smithikrai, Longthong, \& Peijsel (2015: 7) menyatakan bahwa sinema/film mampu menjadi alat yang kuat untuk meningkatkan karakteristik positif dan mengurangi karakter negatif. Hal ini disebabkan oleh film yang bersangkutan menceritakan wilayah yang diinginkan dan diketahui. Wilayah tersebut ingin dicapai individu agar hidupnya berkualitas dan wilayah tersebut akan dihubungkan ke dalam dirinya hingga menghasilkan perasaan yang lebih baik, lebih kuat, dan lebih sejahtera ke dalam perilaku yang sehat. Di lain pihak, Gentile et al. (2009: 753) mengemukakan bahwa konten yang dikandung oleh sebuah film akan sangat berefek dalam meningkatkan keterampilan khusus yang mendidik. Penonton menjadi terpengaruh melalui perilaku yang digambarkan melalui film.
Pengaruh ini disebabkan oleh stimulus yang diberikan oleh tayangan yang ditampilkan oleh film.

Pada siswa kelompok kontrol tidak terjadi peningkatan perilaku prososial yang begitu signifikan. Melalui uji statistik diketahui bahwa layanan informasi sebagai perlakuan yang diberikan ternyata secara signifikan kurang mampu meningkatkan perilaku prososial siswa. Ketidakmampuan pemberian layanan informasi dalam meningkatkan perilaku prososial pada siswa terlihat pada substansi pemberian layanan informasi yang pada dasarnya merupakan pemberian pengajaran melalui pemberian informasi yang bersifat instruksional. Strategi ini lebih dititikberatkan pada pemrosesan informasi secara klasikal. Pelayanan instruksional yang bersifat informatif cenderung akan gagal jika kurang mendapat perhatian dari sasaran layanan bimbingan.

Hal lain yang berpotensi besar menghambat efektivitas layanan informasi adalah guru BK terjebak pada upaya pemberian nasihat. Prayitno \& Amti (2013: 123) mengemukakan bahwa pemberian nasihat hanya merupakan sebagian kecil dari upaya-upaya BK. Di samping pemberian nasihat, pada umumnya konseli sesuai dengan masalah yang dialaminya, memerlukan pula pelayanan lain, seperti pemberian informasi, penempatan dan penyaluran, konseling, bimbingan belajar, alih tangan kepada petugas yang lebih berwenang, dan lain sebagainya. Selain itu, guru BK kurang mampu melakukan variasi dan mencoba mencari formula baru dalam praktik pelaksanaan BK. Hal ini mengakibatkan konseli menjadi jenuh dan pelayanan BK tidak menghasilkan hasil seperti yang diharapkan oleh konseli.

Pada akhirnya besarnya manfaat yang diberikan oleh cinematherapy ini hendaknya mampu diterapkan dalam kehidupan sehari-hari dalam menangani permasalahan yang terjadi pada individu. Bagi guru BK, implikasi hasil penelitian ini adalah bahwa guru BK dapat menerapkan teknik cinematherapy dalam penanganan masalah sosial yang dialami oleh siswa. Selain itu, perlu diupayakan pengembangan teknik ini dalam membantu siswa dalam memecahkan permasalahan yang terjadi pada bidang kehidupan lain yang dimiliki oleh siswa. 


\section{SIMPULAN DAN SARAN}

Berdasarkan hasil penelitian dapat dikemukakan beberapa kesimpulan sebagai berikut: (1) Tingkat perilaku prososial pada siswa kelas VIII Bosowa International School Makassar, berdasarkan hasil pretest baik itu kelompok eksperimen maupun kontrol berada pada kategori rendah. Namun demikian, setelah diberi perlakuan berupa cinematherapy untuk kelompok eksperimen menunjukkan perubahan dari tingkat perilaku prososial rendah menjadi kategori tinggi. Sementara itu, bagi kelompok kontrol yang tidak diberi cinematherapy tidak menunjukkan perubahan yang signifikan; (2) Penerapan cinematherapy mampu meningkatkan perilaku prososial pada siswa kelas VIII di Bosowa International School Makassar.

Selanjutnya, diajukan saran-saran sebagai berikut: (1) Upaya penerapan cinematherapy sebagai teknik dalam konseling membutuhkan sarana dan prasarana yang memadai, khususnya berkaitan dengan tempat pelaksanaan serta sarana penunjang seperti LCD dan laptop. Olehnya itu, pihak sekolah hendaknya menyediakan ruang konseling serta memfasilitasi unit BK dengan perbaikan pada penyediaan sarana yang berhubungan dengan pelaksanaan cinematherapy; (2) Cinematherapy merupakan sebuah teknik yang kreatif dan inovatif. Olehnya itu, guru BK wajib senantiasa untuk peka terhadap kemajuan di bidang entertainment. Guru BK pula hendaknya mampu menganalisis makna yang tersirat di dalam sebuah video maupun film yang berpotensi menjadi sebuah wahana terapeutik bagi permasalahan yang dihadapi oleh siswa; (3) Bagi peneliti lanjutan, perlu dikembangkan cinematherapy yang mampu dioperasionalkan pada bidang lain mengingat masalah yang dihadapi oleh siswa berbeda-beda, dan diharapkan peneliti lanjutan menggunakan teknik pengambilan sampel yang sifatnya mampu menggeneralisasikan hasil penelitian yang dilakukan.

\section{DAFTAR RUJUKAN}

Faturrohman. (2009). Pengantar Psikologi Sosial. Yogyakarta: Pustaka Pelajar.

Gentile, D.A., Anderson, C.A., Yukawa, S., Ihori, N., Saleem, M., Ming, L.K., Shibuya, A., Liau, A.K., Khoo, A.,
Bushman, B.J., Huesmann, L.R., \& Sakamoto, A. (2009). The Effects of Prosocial Video Games on Prosocial Behaviors: International Evidence From Correlational, Longitudinal, and Experimental Studies. Personality and Social Psychology, 35 (6), 752 - 763.

Isnandar. (2010). Hubungan antara Konsep Diri dengan Perilaku Prososial pada SMA 1 Purworejo: Skripsi (tidak diterbitakan).

Joseph, A.E. (2015). Reel Therapy: Using Movie in Counseling and Psychotherapeutic Practice. International Journal of Scientific \& Engineering Research, 6 (8), 2100-2108.

Asih, G.Y. (2010). Perilaku Prososial Ditinjau dari Empai dan Kematangan Emosi. Jurnal Psikologi UMK, 1 (1), 33-42.

Nurjanah, E. (2013). Pengaruh Media Film Terhadap Motivasi Belajar Dalam Pembelajaran Pendidikan Kewarganegaraan (PKn). Tesis. Bandung: Universitas Pendidikan Indonesia.

Prayitno \& Amti, E. (2013). Dasar-Dasar Bimbingan dan Konseling. Jakarta: PT. Rineka Cipta.

Smithikrai, C., Longthong, N., \& Peijsel, C. (2015). Effect of Using Movies to Enhance Personal Responsibility of University Students. Asian Social Science, 15, (5), 1 -9.

Taylor, S.E., et al. (2009). Psikologi Sosial. Jakarta: Kencana Prenada Media Group.

Sopian. (2015). Efektivitas Teknik Cinematherapy Untuk Meningkatkan Efikasi Akademik. Tesis. Universitas Pendidikan Indonesia.

Yazici, E., Ulus, F., Selvitop, R., Yazici, A.B., \& Aydin, N. (2014). Use of Movies for Group Therapy of Psychiatric Inpatients: Theory and Practice, International Journal Of Group Psychotherapy, 64 (2), $255-270$. 